\title{
PENGARUH EKSTRAK DAUN THE HIJAU (CAMELLIA SINENSIS) PADA PEMBUATAN NAGET DAGING SAPI TERHADAP DAYA AWET
}

\section{THE INFLUENCE OF GREEN TEA LEAF (CAMELLIA SINENSIS) EXTRACT ON THE PROCESS OF MAKING BEEF NUGGETS FOR SHELF LIFE}

\author{
AF Faiqoh1a, L Suryaningsih1, J Gumilar1 \\ 1Jurusan Peternakan Fakultas Peternakan Universitas Padjadjaran, Jl Raya Bandung - Sumedang KM \\ 21 Sumedang 45363. \\ aKorespondensi :Areza Febryanti, email: arezafebryanti@gmail.com
}

(Received : 14-10-2019; Accepted : 20-12-2019)

\begin{abstract}
Green tea (Camellia sinensis) contains active compounds in the form of polyphenols which can function as natural preservatives for food products as nuggets. This study was conducted to study the effect of using green tea leaf extract on the process of making beef nuggets for shelf life (total number of bacteria, rancidity and early spoilage), and determine the best concentration of green tea leaf extract which can produce the best preservation of beef nuggets. This research was conducted at the Animal Product Processing Technology Laboratory (TPPP), Faculty of Animal Husbandry and Test Service Laboratory, Faculty of Agricultural Industrial Technology, Padjadjaran University on March 2019. This research was conducted experimentally using a Randomized Complete Design with the utilization of green tea leaf extract in $0,0.5,1$, and $1.5 \%$, the measured variable is the total number of bacteria, rancidity and early spoilage. The results showed that the addition of green tea leaf extract $0,5 \%\left(\mathrm{P}_{2}\right), 1 \%\left(\mathrm{P}_{3}\right)$, and 1,5\% $\left(\mathrm{P}_{4}\right)$ had a significant effect $(\mathrm{P}<0,05)$ on the total number of bacteria, value of rancidity and time of early spoilage compared to $0 \%\left(\mathrm{P}_{1}\right)$. Addition of green tea leaf extract in $1.5 \%$ to beef nuggets gave the best results for the shelf life of beef nuggets with the total number of bacteria $99.71 \times 105 \mathrm{CFU} / \mathrm{g}$, the value of rancidity $0.53 \mathrm{mg}$ malonaldehyde/kg, and the time of early spoilage was 1061.20 minutes.
\end{abstract}

Key words : green tea, Nuggets, total number of bacteria, rancidity, early spoilage

\begin{abstract}
ABSTRAK
Teh hijau (Camellia sinensis) mengandung senyawa aktif berupa polifenol yang dapat berfungsi sebagai pengawet alami untuk produk pangan seperti naget daging sapi. Penelitian ini untuk mempelajari pengaruh penggunaan ekstrak daun teh hijau pada proses pembuatan naget daging sapi terhadap daya awet (jumlah total bakteri, ketengikan dan awal kebusukan), serta menentukan konsentrasi terbaik pemberian ekstrak daun teh hijau yang dapat menghasilkan naget sapi dengan daya awet terbaik. Penelitian ini dilaksanakan di Laboratorium Teknologi Pengolahan Produk Peternakan (TPPP) Fakultas Peternakan dan Laboratorium Jasa Uji Fakultas Teknologi Industri Pertanian, Universitas Padjadjaran pada bulan Maret 2019. Penelitian ini dilakukan secara eksperimen menggunakan Rancangan Acak Lengkap dengan penggunaan ekstrak daun teh hijau pada konsentrasi $0,0,5,1$, dan 1,5\%, variabel yang diukur yaitu jumlah total bakteri, ketengikan dan awal kebusukan. Hasil penelitian menunjukkan bahwa dengan adanya penambahan ekstrak daun teh hijau 0,5\% $\left(\mathrm{P}_{2}\right), 1 \%\left(\mathrm{P}_{3}\right)$, dan 1,5\% $\left(\mathrm{P}_{4}\right)$ memberikan hasil yang berpengaruh nyata $(\mathrm{P}<0,05)$ terhadap jumlah total bakteri, nilai ketengikan dan waktu awal kebusukan dibandingkan dengan $0 \%\left(\mathrm{P}_{1}\right)$. Pemberian ekstrak daun teh hijau sebesar $1,5 \%$ pada naget daging sapi memberikan daya awet terbaik dengan jumlah total bakteri naget daging sapi 99,71 $\times 10^{5} \mathrm{CFU} / \mathrm{g}$, nilai ketengikan naget daging sapi dan 0,53 mg malonaldehid/kg, dan waktu awal kebusukan 1061,20 menit.
\end{abstract}

Kata kunci : teh hijau, naget, jumlah total bakteri, ketengikan, awal kebusukan 
AF Faiqoh, L Suryaningsih dan J gumilar. 2020. Pengaruh Ekstrak Daun The Hijau (Camellia Sinensis) Pada Pembuatan Naget Daging Sapi Terhadap Daya Awet. Jurnal Peternakan Nusantara 6(2):7582.

\section{PENDAHULUAN}

Daging merupakan produk pangan utama selain susu dan telur yang dihasilkan oleh ternak unggas, ruminansia dan non ruminansia. Daging berperan sebagai penyedia sumber protein hewani dan nutrisi lainnya, sehingga dapat digunakan untuk memenuhi kebutuhan nutrisi manusia. Daging sapi cukup diminati oleh konsumen di Indonesia.

Daging sapi cukup diminati oleh konsumen karena memiliki kandungan nutrisi yang baik serta memiliki warna merah, bau yang khas dan memiliki tekstur empuk. Namun tidak semua bagian daging sapi disukai oleh konsumen, khususnya bagian daging yang mengandung banyak lemak seperti daging bagian flank. Kurangnya minat konsumen akan bagian tersebut membuat nilai jual daging flank menjadi rendah, karena daging dinilai mudah tengik dan berdaya awet rendah.

Pengolahan daging merupakan upaya yang tepat untuk menangani permasalahan tersebut. Salah satu teknik pengolahan daging yang dapat digunakan ialah mengolah daging tersebut menjadi naget. Naget merupakan salah satu produk olahan daging yang digiling, dicetak, dimasak dan dibekukan serta terbuat dari campuran daging giling yang diberi bahan pelapis atau tanpa penambahan bahan makanan lain dan bahan tambahan makanan yang telah diizinkan (BSN, 2002).

Naget sapi dapat terbuat dari potongan daging sapi bagian flank. Lemak pada dagian bagian flank dapat membuat naget sapi mudah mengalami proses ketengikan akibat adanya proses oksidasi lemak (Denny, 2010). Selain itu, adanya kandungan nutrisi lain seperti protein dan karbohidrat pada naget tersebut dapat menimbulkan kerusakan akibat aktivitas mikroba. Kandungan nutrisi tersebut berperan sebagai sumber energi bagi mikroba yang mendukung keberlangsungan hidup mikroba. Adanya aktivitas mikroba dan proses ketengikan tersebut akan membuat naget menjadi tengik dan busuk, sehingga naget tidak layak dikonsumsi oleh konsumen (Srikandi, 1992).

Upaya untuk meminimalkan terjadinya kerusakan bahan pangan karena adanya pertumbuhan mikroba adalah dengan melakukan pengawetan (Effendi, 2009). Pada pengolahan naget biasanya ditambahkan bahan pengawet untuk memperpanjang daya simpan. Bahan pengawet yang digunakan berasal dari pengawet sintetik seperti butylated hydroxytoluence (BHT) dan butylated hydroxyanisole (BHA). Penggunaan bahan pengawet sintetik menimbulkan resiko karsinogenik, sehingga penggunaannya dilarang pada beberapa negara. Upaya yang dapat dilakukan untuk mencegah adanya resiko karsinogenik tersebut ialah dengan cara menggunakan pengawet alami. Salah satu contoh bahan alami yang dapat digunakan sebagai pengawet alami untuk produk pangan ialah ekstrak daun teh hijau (Camellia sinensis) padat (Bozkurt, 2006).

Teh hijau dalam bentuk daun segar memiliki kandungan senyawa polifenol sebesar $10,81 \%$, sedangkan teh hijau dalam bentuk ekstrak padat memiliki kandungan senyawa polifenol berkisar antara 37-56\% berat kering (Hartoyo, 2003). Kandungan polifenol pada teh hijau dapat meningkat hingga 36\% (dalam basis kering) tergantung iklim, musim atau varietasnya (Wanasundara dan Shahidi, 1998).

Senyawa polifenol berperan sebagai antioksidan alami, antibakteri, dan mampu mengurangi oksidasi lipid pada naget sapi. Sifat antioksidan dari ekstrak teh hijau disebabkan oleh adanya katekin, apicatechins, epicatechin gallate, epigallocatechin, dan epigallocatechin gallate (Higdon dan Frei, 2003). Sifat antibakteri dari ekstrak teh hijau disebabkan oleh adanya flavonoid. Flavonoid merupakan turunan dari senyawa fenol yang bekerja sebagai antimikroba (Naidu dan Clemens, 2000).

Penelitian ini bertujuan untuk mengetahui pengaruh pemberian ekstrak daun teh hijau (Camellia sinensis) terhadap daya awet (jumlah total bakteri, ketengikan dan awal kebusukan) naget sapi, dan konsentrasi berapa persen penggunaan ekstrak daun teh hijau (Camellia sinensis) yang dapat menghasilkan naget sapi dengan daya awet terbaik. 


\section{MATERI DAN METODE}

\section{Materi}

Bahan utama dalam penelitian ini adalah daging sapi Australian Commercial Cross (ACC) berumur 2 - 3 tahun, bagian flank sebanyak $4 \mathrm{~kg}$ yang didapatkan dari Rumah Potong Hewan (RPH) PT. Dilar Lintas Raya, Tasikmalaya. Ekstrak daun teh hijau yang digunakan adalah ekstrak daun teh hijau cair.

Bumbu yang digunakan diantaranya bawang putih sebanyak 250 gram, lada bubuk sebanyak 100 gram, dan garam sebanyak 250 gram. Tepung terigu sebanyak 500 gram dan tepung panir sebanyak $1 \mathrm{~kg}$ yang digunakan sebagai bahan pembungkus naget. Bahan yang digunakan untuk uji TPC diantaranya aquadest, alkohol, spirtus, $\mathrm{NaCl}$ fisiologis dan natrium agar. Bahan yang digunakan untuk pengujian awal kebusukan diantaranya yaitu larutan $\mathrm{Pb}$ Asetat, dan bahan yang digunakan untuk pengujian TBA yaitu $\mathrm{HCl}$ dan asam tiobarbiturat.

Peralatan yang digunakan dalam penelitian ini meliputi alat destilasi, autoclave, bacterial colony counter, baker glass, baskom, batang pengaduk, blander, cawan petri, food processor, gunting, kalkulator, kertas sampul, kertas label, kertas whatman no. 41, kompor, laminar air flow, mangkok, masker, mortal alu, pembakar bunsen, pengukus, pipet tetes, piring kertas, pisau, pipet ukur, sarung tangan, sendok, spektrofotometer, tabung erlenmeyer, tabung reaksi, talenan, dan timbangan analitik.

\section{Perlakuan}

Perlakuan yang diberikan terdiri atas empat macam penggunaan ekstrak daun teh hijau (ETH) terhadap naget daging sapi dengan tingkat pemberian ekstrak yang berbeda, yakni: Naget sapi + ETH $0 \%\left(\mathrm{P}_{1}\right)$, naget sapi + ETH $0,5 \%\left(\mathrm{P}_{2}\right)$, naget sapi + ETH $1 \%\left(\mathrm{P}_{3}\right)$, dan naget sapi + ETH 1,5\% $\left(\mathrm{P}_{4}\right)$.

\section{Rancangan Percobaan}

Rancagan yang digunakan dalam penelitian ini adalah Rancangan Acak Lengkap (RAL). Model matematika dalam percobaan ini menurut Gaspersz (2006) adalah sebagai berikut :

$$
\mathbf{Y}_{\mathrm{ij}}=\boldsymbol{\mu}+\boldsymbol{\alpha}_{\mathrm{i}}+\varepsilon_{\mathrm{ij}}
$$

Keterangan:

Yij: Respon atau nilai pengamatan dari perlakukan ke-i dan ulangan ke-j

$\mu$ : Nilai tengah umum (rata-rata) $\alpha \mathrm{i}$ : Pengaruh perlakukan ke-i

$\varepsilon$ ij: Galat percobaan dari perlakuan ke-i dan ulangan ke-j

i: Percobaan ke-i $(1,2,3,4)$

$\mathrm{j}$ : Ulangan ke-j $(1,2,3,4,5)$

\section{Peubah yang Diamati}

Jumlah Total Bakteri

Pengujian jumlah total bakteri pada naget menggunakan metode Total Plate Count (TPC). Total Plate Count (TPC) adalah jumlah mikroba aerob per milliliter sampel yang ditentukan melalui metode standar. Perlunya dilakukan pengujian jumlah total bakteri dilakukan untuk mengetahui jumlah bakteri total pada produk naget sapi dengan ekstrak daun teh hijau. Penghitungan jumlah total bakteri dilakukan mengunakan metode Pour Plate Methode (Modifikasi Denny dan Trioso, 2009).

\section{Ketengikan}

Uji ketengikan dilakukan untuk menentukan derajat ketengikan dengan mengukur senyawasenyawa hasil oksidasi. Uji ketengikan dilakukan dengan metode uji bilangan TBA berdasarkan atas terbentuknya pigmen berwarna merah sebagai hasil dari reaksi kondensasi antara 2 molekul TBA dengan 1 molekul malonaldehid. Tujuan dilakukan uji TBA untuk mengetahui adanya reaksi lebih lanjut pada lemak yang menyebabkan ketengikan (Sudarmadji, dkk., 1996).

\section{Awal Kebusukan}

Pemeriksaan awal kebusukan naget menggunakan metode Denny dan Purnawarman (2009) yang telah dimodifikasi yaitu pemeriksaan awal kebusukan dengan $\mathrm{Pb}$-asetat. Gas $\mathrm{H}_{2} \mathrm{~S}$ yang dihasilkan pada awal proses pembusukan akan berekasi dengan $\mathrm{Pb}$-asetat dan menghasilkan warna hitam.

\section{Analisis Data}

Data yang diperoleh dianalisis dengan sidik ragam (ANOVA) dan jika perlakuan berpengaruh nyata terhadap peubah yang diamati maka analisis dilanjutkan dengan uji lanjut jarak ganda Duncan dengan menggunakan bantuan piranti program SPSS 16. 


\section{Prosedur Pelaksanaan}

Sterilisasi Alat

Proses sterilisasi alat menggunakan metode Volk dan Wheeler (1993) sebagi berikut yaitu alat-alat yang akan digunakan disterilkan dalam autoclave pada suhu $121^{\circ} \mathrm{C}$ selama 15 menit.

\section{Ekstrak Daun Teh Hijau}

Daun teh hijau kering sebanyak 20 gram direndam dengan $500 \mathrm{ml}$ air mendidih selama 5 menit. Esktrak daun teh hijau didapatkan melalui proses penyaringan (Bozkurt, 2006). Ekstrak daun teh hijau (Camellia sinensis) yang digunakan sebagai pengawet alami akan ditambahkan pada adonan naget sapi dengan 4 konsentrasi, masing-masing $0,0,5,1$, dan 1,5\% dari berat daging.

\section{Pembuatan Naget Sapi}

Pembuatan naget sapi dilakukan dengan cara menggiling daging terlebih dahulu, setelah digiling kemudian daging tersebut ditambahkan dengan telur, tepung tapioka dan susu bubuk untuk membentuk adonan. Adonan yang terbentuk kemudian ditambahkan bumbu yang sudah dihaluskan meliputi bawang putih, garam dan lada bubuk, kemudian ditambahkan ekstrak daun teh hijau untuk masing-masing perlakuan sebesar 0, 0,5, 1 dan 1,5\%, lalu aduk hingga merata.

Adonan yang sudah tercampur rata kemudian dimasukan ke loyang, lalu dikukus selama 30 menit dengan suhu $66-82^{\circ} \mathrm{C}$. Adonan yang sudah matang ditiriskan, kemudian dimasukan dalam lemari pendingin selama \pm 30 menit, lalu dipotong-potong dengan ukuran $1 \times 3 \mathrm{~cm}$ dengan ketebalan 1,5 cm. Naget yang telah dipotong kemudian dilumuri dengan tepung terigu dan tepung panir, kemudian produk naget sapi siap untuk dianalisis (Thohari, dkk., 2017). Formulasi pembuatan naget daging sapi disajikan pada Tabel 1.
Tabel 1 Formulasi Produk Naget Sapi

\begin{tabular}{|c|c|c|c|c|}
\hline \multirow[b]{2}{*}{ Bahan } & \multicolumn{4}{|c|}{ Perlakuan } \\
\hline & P1 & P2 & P3 & P4 \\
\hline & \multicolumn{4}{|c|}{............ $\operatorname{gram}, \ldots \ldots \ldots \ldots$} \\
\hline \multicolumn{5}{|c|}{ Bahan Utama } \\
\hline $\begin{array}{l}\text { Daging } \\
\text { Sapi }\end{array}$ & 200,00 & 200,00 & 200,00 & 200,00 \\
\hline $\begin{array}{l}\text { Ekstrak } \\
\text { Teh Hijau }\end{array}$ & 0,00 & 1,00 & 2,00 & 3,00 \\
\hline \multicolumn{5}{|c|}{ Bahan Tambahan } \\
\hline $\begin{array}{l}\text { Tepung } \\
\text { Tapioka }\end{array}$ & 20,00 & 20,00 & 20,00 & 20,00 \\
\hline $\begin{array}{l}\text { Telur } \\
\text { Ayam }\end{array}$ & 0,06 & 0,06 & 0,06 & 0,06 \\
\hline $\begin{array}{l}\text { Susu } \\
\text { Bubuk }\end{array}$ & 12,00 & 12,00 & 12,00 & 12,00 \\
\hline $\begin{array}{l}\text { Total } \\
\text { Adonan }\end{array}$ & 232,06 & 233,06 & 234,06 & 235,06 \\
\hline \multicolumn{5}{|c|}{ Bumbu } \\
\hline $\begin{array}{l}\text { Bawang } \\
\text { Putih }\end{array}$ & 4,64 & 4,66 & 4,68 & 4,70 \\
\hline $\begin{array}{l}\text { Lada } \\
\text { Bubuk }\end{array}$ & 4,64 & 4,66 & 4,68 & 4,70 \\
\hline Garam & 4,64 & 4,66 & 4,68 & 4,70 \\
\hline Total & 245,98 & 247,04 & 248,10 & 249,16 \\
\hline
\end{tabular}

Sumber: Thohari et al (2017) yang dimodifikasi.

\section{HASIL DAN PEMBAHASAN}

\section{Jumlah Total Bakteri}

Hasil analisis ragam mengenai pengaruh perlakuan terhadap jumlah total bakteri pada naget daging sapi memberikan pengaruh nyata $(\mathrm{P}<0,05)$, selanjutnya dilakukan uji jarak berganda Duncan untuk mengetahui perbedaan pengaruh antar perlakuan. Hasil uji jarak bergandan duncan tertera pada Tabel 2 .

Tabel 2 Hasil Uji Jarak Berganda Duncan Pengaruh Perlakuan terhadap Jumlah Total Bakteri Naget Daging Sapi Sesudah Penyimpanan

\begin{tabular}{cc}
\hline Perlakuan & Rataan Total Mikroba \\
\hline & $\left(\times 10^{5} C F U / g\right)$ \\
$\mathrm{P}_{4}$ & $99,71^{\mathrm{a}} \pm 19,95$ \\
$\mathrm{P}_{3}$ & $104,83^{\mathrm{a}} \pm 10,07$ \\
$\mathrm{P}_{2}$ & $110,22^{\mathrm{a}} \pm 14,95$ \\
$\mathrm{P}_{1}$ & $220,12^{\mathrm{b}} \pm 34,18$ \\
\hline
\end{tabular}

Keterangan : Huruf kecil yang berbeda pada kolom signifikansi menunjukan hasil yang berbeda nyata $(\mathrm{P}<0,05)$. 
Hasil uji jarak berganda Duncan pada Tabel 2. menunjukkan bahwa konsentrasi $0 \%\left(\mathrm{P}_{1}\right)$ nyata $(\mathrm{P}<0,05)$ memiliki populasi bakteri yang lebih tinggi dibandingkan dengan konsentrasi $0,5 \%\left(\mathrm{P}_{2}\right), 1 \%\left(\mathrm{P}_{3}\right)$, dan $1,5 \%\left(\mathrm{P}_{4}\right)$. Tingginya jumlah total bakteri pada naget $\mathrm{P}_{1}$ disebabkan oleh tidak adanya senyawa antibakteri yang dapat menghambat pertumbuhan bakteri (Hingdon dan Frei, 2003 ; Anwar, dkk., 2007). Sedangkan, jumlah total bakteri pada konsentrasi $0,5 \%\left(\mathrm{P}_{2}\right), 1 \%\left(\mathrm{P}_{3}\right)$, dan 1,5\% $\left(\mathrm{P}_{4}\right)$ masing-masing tidak berbeda nyata. Hal tersebut disebabkan oleh kandungan flavonoid yang terdapat pada naget $\mathrm{P}_{1}, \mathrm{P}_{2}$ dan $\mathrm{P}_{3}$ tidak jauh berbeda karena tingkat penambahan konsentrasi ekstrak teh hijau tidak terlalu tinggi, tetapi mampu menghambat pertumbuhan bakteri pada naget daging sapi. Hal ini serupa dengan penelitian yang dilakukan oleh Rifda dan Herastuti (2013), dimana pemberian ekstrak kecombrang dengan konsentrasi 1, 2 dan 3\% tidak memberikan perbedaan yang signifikan namun mampu menghambat pertumbuhan bakteri karena adanya kandungan senyawa flavonoid pada naget ayam yang berasal dari ekstrak kecombrang.

Golongan flavonoid yang terkandung dalam teh hijau bekerja sebagai antibakteri yang dapat bersifat bakteriostatik atau bakterisidal tergantung konsentrasinya. Flavonoid dapat bekerja dengan cara merusak dinding sel bakteri dan membran sitoplasmanya sehingga menyebabkan denaturasi protein (Anwar, dkk., 2007). Denaturasi protein tersebut dapat menyebabkan aktivitas metabolisme sel bakteri berhenti karena semua aktivitas metabolisme sel bakteri dikatalis oleh suatu enzim yang merupakan protein, dan mengakibatkan kematian sel bakteri (Trease dan Evans, 1987). Sehingga, ekstrak daun teh hijau ini dapat dimanfaatkan untuk meningkatkan daya awet naget daging sapi.

\section{Ketengikan}

Hasil uji ketengikan menunjukkan bahwa pemberian ekstrak daun teh hijau pada naget daging sapi memberikan efek yang berbeda nyata $(\mathrm{P}<0,05)$. Selanjutnya, dilakukan uji jarak berganda Duncan untuk mengerahui perbedaan pengaruh antar perlakuan terhadap nilai ketengikan yang ditampilkan pada Tabel 3 .
Tabel 3 Hasil Uji Jarak Berganda Duncan Pengaruh Perlakuan terhadap Ketengikan Naget Daging Sapi Sesudah Penyimpanan

\begin{tabular}{cc}
\hline Perlakuan & Rataan nilai ketengikan \\
\hline & $(m g$ malonaldehid $/ \mathrm{kg})$ \\
$\mathrm{P}_{4}$ & $0,53^{\mathrm{a}} \pm 0,18$ \\
$\mathrm{P}_{3}$ & $0,74^{\mathrm{a}} \pm 0,41$ \\
$\mathrm{P}_{2}$ & $0,94^{\mathrm{a}} \pm 0,37$ \\
$\mathrm{P}_{1}$ & $1,67^{\mathrm{b}} \pm 0,66$ \\
\hline
\end{tabular}

Keterangan : Huruf kecil yang berbeda pada kolom signifikansi menunjukan hasil yang berbeda nyata $(\mathrm{P}<0,05)$.

Hasil uji jarak berganda Duncan pada Tabel 3. menunjukkan bahwa pemberian ekstrak daun teh hijau pada naget sapi dengan konsentrasi $0 \% \quad\left(\mathrm{P}_{1}\right)$ nyata $(\mathrm{P}<0,05)$ memiliki nilai ketengikan yang paling tinggi dibandingkan dengan konsentrasi $0,5 \%\left(\mathrm{P}_{2}\right), 1 \%\left(\mathrm{P}_{3}\right)$, dan $1,5 \%\left(\mathrm{P}_{4}\right)$. Tingginya nilai ketengikan pada naget $\mathrm{P}_{1}$ disebabkan oleh tidak adanya senyawa antioksidan yang dapat menghambat oksidasi lemak (Hingdon dan Frei, 2003). Sedangkan, nilai ketengikan pada konsentrasi $0,5 \%\left(\mathrm{P}_{2}\right), 1 \%$ $\left(\mathrm{P}_{3}\right)$, dan $1,5 \% \quad\left(\mathrm{P}_{4}\right)$ masing-masing tidak berbeda nyata. Hal tersebut disebabkan oleh penambahan konsentrasi antar perlakuan yang tidak terlalu besar, sehingga kandungan antioksidan pada naget $\mathrm{P}_{1}, \mathrm{P}_{2}$ dan $\mathrm{P}_{3}$ tidak berbeda nyata tetapi mampu menghambat oksidasi lemak pada naget daging sapi. Menurut Naghma dan Hassan (2007), teh hijau memiliki sifat fungsional sebagai antioksidan yang dihasilkan oleh senyawa polifenol, semakin meningkatnya konsentrasi ekstrak teh hijau maka akan diikuti dengan peningkatan yang nyata $(\mathrm{P}<0,05)$ pada kadar polifenol naget daging sapi.

Hingdon dan Frei (2003) yang menyatakan bahwa sifat antioksidan pada ekstrak daun teh hijau disebabkan oleh adanya katekin. Katekin teh dan dan senyawa polifenol lainnya merupakan pengikat radikal bebas yang mampu menghambat oksidasi lemak. Aktivitas antioksidan polifenol teh hijau disebabkan oleh kombinasi cincin aromatik dan gugus hidroksil yang menyusun struktur kimianya. Kelompok hidroksil tersebut mampu mengikat dan menetralkan radikal bebas lipid. Velayutham, dkk., (2008) menambahkan bahwa katekin teh hijau juga menunjukkan aktivitas antioksidan dengan cara menghambat enzim pro-oksidan dan menginduksi enzim antioksidan 


\section{Awal Kebusukan}

Hasil analisis ragam mengenai pengaruh perlakuan terhadap awal kebusukan naget daging sapi memberikan pengaruh nyata $(\mathrm{P}<0,05)$. Selanjutnya, dilakukan uji jarak berganda Duncan untuk mengerahui perbedaan pengaruh antar perlakuan terhadap awal kebusukan yang hasilnya ditampilkan pada Tabel 4.

Tabel 4 Hasil Uji Jarak Berganda Duncan Pengaruh Perlakuan terhadap Awal Kebusukan Naget Daging Sapi

\begin{tabular}{cc}
\hline Perlakuan & Daya Awet \\
\hline & $\ldots($ menit $) \ldots$ \\
$\mathrm{P}_{1}$ & $400,60^{\mathrm{a}} \pm 215,69$ \\
$\mathrm{P}_{2}$ & $833,40^{\mathrm{b}} \pm 197,40$ \\
$\mathrm{P}_{3}$ & $1013,00^{\mathrm{b}} \pm 419,31$ \\
$\mathrm{P}_{4}$ & $1061,20^{\mathrm{b}} \pm 350,78$ \\
\hline
\end{tabular}

Keterangan : Huruf kecil yang berbeda pada kolom signifikansi menunjukan hasil yang berbeda nyata $(\mathrm{P}<0,05)$.

Hasil uji jarak berganda Duncan pada Tabel 4. menunjukkan bahwa pemberian ekstrak daun teh hijau pada naget sapi dengan konsentrasi $0 \% \quad\left(\mathrm{P}_{1}\right)$ nyata $(\mathrm{P}<0,05)$ memiliki waktu kebusukan yang lebih cepat dibandingkan dengan konsentrasi $0,5 \%\left(\mathrm{P}_{2}\right), 1 \%\left(\mathrm{P}_{3}\right)$, dan $1,5 \%\left(\mathrm{P}_{4}\right)$. Hal tersebut terjadi karena naget $\mathrm{P}_{1}$ tidak mengandung senyawa aktif berupa flavonoid yang bersifat antibakteri dan dapat mencegah terjadinya produksi gas $\mathrm{H}_{2} \mathrm{~S}$ (Susmono dan Wulan, 2009). Sehingga pemberian ekstrak daun teh hijau dengan konsentrasi $0,5 \%\left(\mathrm{P}_{2}\right), 1 \%\left(\mathrm{P}_{3}\right)$, dan 1,5\% $\left(\mathrm{P}_{4}\right)$ pada naget daging sapi, dinilai mampu menghambat produksi gas hidrogen sulfida $\left(\mathrm{H}_{2} \mathrm{~S}\right)$ yang dihasilkan oleh mikroba pada naget daging sapi. Hal tersebut sesuai dengan pendapat Kristam, dkk., (2016), yang menyatakan bahwa ekstrak daun teh hijau yang ditambahkan pada produk makanan bersifat sebagai antibakteri yang dapat menghambat aktifitas bakteri.

Data pada Tabel 4. menunjukan lama waktu kebusukan pada konsentrasi $0,5 \%\left(\mathrm{P}_{2}\right), 1 \%\left(\mathrm{P}_{3}\right)$, dan $1,5 \%\left(\mathrm{P}_{4}\right)$ masing-masing tidak berbeda nyata. Hal tersebut disebabkan kandungan polifenol yang terdapat pada naget $\mathrm{P}_{1}, \mathrm{P}_{2}$, dan $\mathrm{P}_{3}$ tidak terlalu berbeda akibat pemberian ekstrak daun teh hijau yang tidak terlalu tinggi. Hal tersebut sesuai dengan pendapat Haskaraca, dkk., (2014), yang menyatakan bahwa kandungan polifenol akan meningkat secara signifikan akibat penambahan konsentrasi ekstrak teh hijau pada naget daging sapi.

Berdasarkan hasil tersebut dapat diketahui bahwa semakin tinggi konsentrasi ekstrak daun teh hijau pada naget daging sapi, maka semakin tinggi pula kandungan zat aktif yang terdapat dalam naget tersebut, sehingga pembentukan gas $\mathrm{H}_{2} \mathrm{~S}$ terhambat dan lama waktu kebusukan meningkat. Menurut Anwar, dkk., (2007) Golongan flavonoid yang terkandung dalam teh hijau, dapat bersifat bakteriostatik atau bakterisidal. Siswandono dan Soekardjo (1995) menambahkan bahwa, Flavonoid merupakan senyawa fenol yang memiliki kerja spektrum luas, dapat merusak dinding sel dan membran sel, mengkoagulasi protein, merusak ATPase, merusak sulfohidril dari protein, dan merusak DNA sehingga efektif membunuh bakteri. Susmono dan Wulan (2009) juga menambahkan bahwa, kerusakan sel bakteri tersebut dapat menghambat pertumbuhan sel bakteri dan produksi gas hidrogen sulfida $\left(\mathrm{H}_{2} \mathrm{~S}\right)$.

\section{KESIMPULAN DAN IMPLIKASI}

\section{Kesimpulan}

Pengaruh penggunaan ekstrak daun teh hijau (Camellia sinensis) pada naget daging sapi berfungsi sebagai pengawet alami yang mampu mengurangi jumlah total bakteri, nilai ketengikan dan memperlambat waktu awal kebusukan naget daging sapi.

Konsentrasi ekstrak daun teh hijau 1,5\% menghasilkan daya awet terbaik (jumlah total bakteri 99,71 × $10^{5} \mathrm{CFU} / \mathrm{g}$, nilai ketengikan 0,53 mg malonaldehid $/ \mathrm{kg}$, dan waktu awal kebusukan 1061,20 menit).

\section{Implikasi}

Penelitian ini diharapkan dapat memberikan informasi baru dalam bidang pengolahan hasil ternak mengenai penggunaan ekstrak daun teh hijau (Camellia sinensis) sebagai pengawet alami untuk produk naget. Penelitian ini juga dapat diterapkan oleh masyarakat dan industri pengolahan daging.

\section{DAFTAR PUSTAKA}

Anwar D A, Supartinah A, Handajani J. 2007. Efek Kumur Ekstrak Teh Hijau (Camellia sinensis) terhadap Derajat Keasaman dan 
Volume Saliva Penderita Gingiitis. Indonesia Journal of Densitry; 14(1):22-6.

Badan Standarisasi Nasional. 2002. Nugget Ayam. SNI 01-6683-2002. Badan Standardisasi Nasional, Jakarta.

Bozkurt, Huseyin. 2006. Pemanfaatan Antioksidan Alami: Ekstrak Teh Hijau dan Minyak Thymbra Spicata dalam Sosis Turki Kering yang Difermentasi. Meat Science 73 (2006) 442-450.

Denny W. Lukman. 2010. Nilai pH Daging. Bagian Kesehatan Masyarakat Veteriner.Fakultas Kedokteran Hewan Institut Pertanian Bogor. Bogor.

Denny W. Lukman., dan T. Purnawarman. 2009. Higiene Pangan. Departemen Ilmu Penyakit Hewan dan Kesmavet. Fakultas Kedokteran Hewan IPB. Bogor.

Effendi HM, Supli. 2009. Teknologi Pengolahan dan Pengawetan Pangan. Alfabeta CV. Bandung.

Hartoyo A. 2003. Teh dan Khasiatnya Bagi Kesehatan. Kaninus. Yogyakarta.

Haskaraca G. Demirok E, Kolsarici N, F. Oz, Ozsarac N. 2014. Effect Of Green Tea Extract And Microwave Pre-Cooking on The Formation of Heterocyclic Aromatic Amines In Fried Chicken Meat Products. Food research international. Ankara.

Higdon JV, Frei B. 2003. Tea Catechins And Polyphenols: Health Effects, Metabolism, And Antioxidant Functions. Critical Reviews in Food Science and Nutrition. Horwood. New York. 43, 89-143.

Kristam P. Naga Malika E, Eswara RB, Srinivas RT. 2016. Evaluation of Edible Polymer Coatings Enriched With Green Tea Extract on Quality of Chicken Nuggets. NTR College of Veterinary Science. Andhra Pradesh.
Naghma K, Hasan M. 2007. Tea Polyphenols for Health Promotion. Life Sciences. 81: 519-533.

Naidu AS, Clemens RA. 2000. Natural Food Antimicrobial System Probiotics. CRC Press. New York.

Rifda N, Erminawati, Rukmini HS. 2013. Aplikasi Pengawet Alami Buah Kecombrang (Nicola speciosa) pada Nugget Ayam. Jurnal Agroteknologi, ISSN 2502-4906.

Siswandono, Soekardjo, B. 1995 Kimia Medisinal. Universitas Airlangga. Surabaya.

Srikandi F. 1992. Mikrbiologi Pangan. Gramedia Pustaka Utama. Jakarta.

Sudarmadji S., Bambang H, Suhardi. 1996. Analisa Bahan Makanan dan Pertanian. Penerbit Liberty. Yogyakarta.

Susmono A, Wulan A. 2009. Kemampuan Air Rebus Daun Salam (Eugenia poluantha w) dalam Menurunkan Jumlah Koloni Bakteri Streptococcus sp. Majalah Farmasi Indonesia. 20 (3), 112-7.

Thohari, Imam., Mustakim, Masdiana CP, Premy PP. 2017. Teknologi Hasil Ternak. UB Press. Malang.

Trease GE, Evans VC. 1987. Pharmacognosy. Edisi 11. Bailliere Tindall. London: 401-403.

Velayutham P, Babu A., Liu D. 2008. Green Tea Catechins and Cardiovascular Health. Current Medicinal Chemistry, 15, 1840-1850.

Volk WA, Wheeler MF. 1993. Mikrobiologi Dasar, Edisi Kelima, Jilid 1. Penerbit Erlangga. Jakarta.

Wanasundara N, Shahidi F. 1998. Omega-3 Fatty Acid Concentrates: Nutrional Aspects and Production Technologies. Journal of Food Science and Technology. 9: 230-240. 
